\title{
Biodegradation of agroindustrial wastes by Pleurotus spp for its use as ruminant feed
}

\author{
Silvana Alborés* \\ Departamento de Biociencias \\ Facultad de Química \\ Universidad de la República \\ Av. Gral. Flores 2124 \\ Montevideo 11800, Uruguay \\ Tel: 059829244209 \\ Fax: 059829241906 \\ E-mail: salbores@fq.edu.uy
María Julia Pianzzola
Departamento de Biociencias Facultad de Química
Universidad de la República Av. Gral. Flores 2124
Montevideo 11800, Uruguay Tel: 059829244209
Fax: 059829241906
E-mail:mpianzzo@fq.edu.uy

\section{Matilde Soubes} \\ Departamento de Biociencias \\ Facultad de Química \\ Universidad de la República \\ Av. Gral. Flores 2124 \\ Montevideo 11800, Uruguay. \\ Tel: 059829244209 \\ Fax: 059829241906 \\ E-mail: msoubes@fq.edu.uy

\section{María Pía Cerdeiras \\ Departamento de Biociencias Facultad de Química Universidad de la República Av. Gral. Flores 2124 \\ Montevideo 11800, Uruguay \\ Tel: 059829244209 \\ Fax: 059829241906 \\ E-mail: mcerdeir@fq.edu.uy}

Financial support: Project INIA-LIA 057, CSIC 308 and by the Maestría en Biotecnología, Facultad de Ciencias, Universidad de la República, Uruguay.

Keywords: agroindustry, basidiomycetes, ruminant feed.

Abbreviations: ADF: acid detergent fibre

$\mathrm{cfg} / \mathrm{g}$ : colony forming units per gram

ITS: internal transcribed spacer region

NDF: neutral detergent fibre

PCR: polymerase chain reaction

RFLP: restriction fragment length polymorphism

SSF: solid substrate fermentation

The increasing expansion of agro-industrial activity has led to the accumulation of a large quantity of lignocellulosic residues all over the world. In particular, large quantities of rice straw (300.000 t) and citric bagasse (50.000 t) are annually produced in Uruguay. In this work we present the study of the bioconversion of these substrates with the edible mushroom Pleurotus spp so as to increase nutritional values and digestibility for its use as animal feed. The SSF process was optimized and the products after different periods of

*Corresponding author 
mushroom growth were evaluated. The microbial counts (cfu/g) for the inoculated substrates 44 days after incubation were $15 \times 10^{4},<10$ and $<10$ for aerobic microorganisms, coliforms and $E$. coli, respectively. After 14 days of SSF the percentage of dry matter, ADF and NDF decreased, and the content of protein increased. These results show that vegetal cell-wall components were degraded during the period of mushroom incubation. PCR - RFLP analysis of the ITS region was used to characterize the Pleurotus species produced in Uruguay and discriminate between DNAs of Pleurotus ostreatus 814 and other fungi from the different substrates.

From the production, processing and consumption of agricultural products, there are a great variety of remainders, which create increasing problems of elimination. In Uruguay, the great majority of the industries that process agricultural products discard their remainders with no treatment, implying a huge aggression to the environment. For example, the citrus processing plants produce 50,000 tons per year of citric bagasse which represents $40-50 \%$ in weight of the fresh fruit. Its composition is relatively adequate for the feeding of ruminants, but present palatability problems and is contaminated with normal flora of the rinds, some of which are mycotoxin producers. With respect to rice straw it is obtained at the rate of $2000 \mathrm{~kg}$ per harvested hectare (310,000 ton of straw per year); and although it is used in the feeding of ruminants, it presents a very low protein content and low digestibility.

Other authors have shown that some fungi, particularly some species of Pleurotus are able to colonize different types of vegetable wastes, increasing their digestibility (Platt et al. 1984; Commanday and Macy, 1985; Rajarathnam and Bano, 1989; Villas-Boas et al. 2002; Zhang et al. 2002; Mukherjee and Nandi, 2004; Salmones et al. 2005). Previous studies have shown the feasibility of using these kind of wastes to produce animal feed (Calzada et al. 1987; Adamovic et al. 1998), and as substrate for mushroom production (Breene, 1990; Sermanni et al. 1994; Kakkar and Dañad, 1998; Yildiz et al. 2002).

In the present work, we study the biodegradation of these wastes by $P$. ostreatus 814 for its use as ruminant feed.

\section{MATERIALS AND METHODS}

\section{Determination of the capacity to grow on the wastes under study}

The strains used in this study ( $P$. ostreatus $814, P$. ostreatus 816, $P$. cornucopiae and $P$. djmour) were provided by Trinidad Mushrooms. They were grown in malt agar $\left(1,25 \%\right.$ malt extract, $1,5 \%$ agar, Oxoid) at $28^{\circ} \mathrm{C}$. The mycelium was then transferred to bottles with sterilized wheat grains and incubated again at $28^{\circ} \mathrm{C}$ until colonization of the substrate was observed (approximately 7 days). These fermented grains were used as inocula $(10 \%$ in weight) for the growth tests in trays at $28^{\circ} \mathrm{C}$ on $500 \mathrm{~g}$ of substrate without sterilizing (citrus bagasse, rice straw and the mixture of both $(1: 9 \mathrm{w} / \mathrm{w}))$.

From these experiments, $P$. ostreatus 814 was the most promising strain.

\section{Evaluation of the characteristics of the fermentation products}

1. Determination of the microbiological quality was performed using Petrifilm (3M). Total aerobes, total coliforms and $E$. coli were determined on the substrates without inoculation and after 44 days of fermentation with P. ostreatus 814 .

2. Analysis of the chemical composition of the fermentation product consisted in the analysis of dry weight (AOAC, 1990), proteins (AOAC, 1990) and neutral and acid detergent fiber (AOAC, 1996) of the different substrates without inoculating and on different days of fermentation with $P$. ostreatus 814 . The results were analyzed using tStudent test with $\mathrm{P}<0.001$.

The significance of the differences were estimated by using the Mann-Whitney U test (Mann and Whitney, 1947), with the limit of significance set at $\mathrm{P}<0,05$. Statistical analyses were performed on SPSS 9.0 Windows.

\section{Molecular characterization}

DNA extraction. Genomic DNA was obtained from pure cultures of fungi belonging to the mushroom producers “Trinidad Mushrooms" (Pleurotus ostreatus 814, Pleurotus

Table 1. Determination of the microbiological quality. The values reported are the mean of two measurements.

\begin{tabular}{|c|c|c|c|}
\hline \multicolumn{3}{|c|}{ Microbial count (cfu/g) } \\
\hline & Total aerobic count & Total coliforms & E. coli \\
\hline Citric bagasse day 0 & $<100$ & $<10$ & $<10$ \\
\hline Fermentation product day 44 & $15 \times 10^{4}$ & $<10$ & $<10$ \\
\hline
\end{tabular}




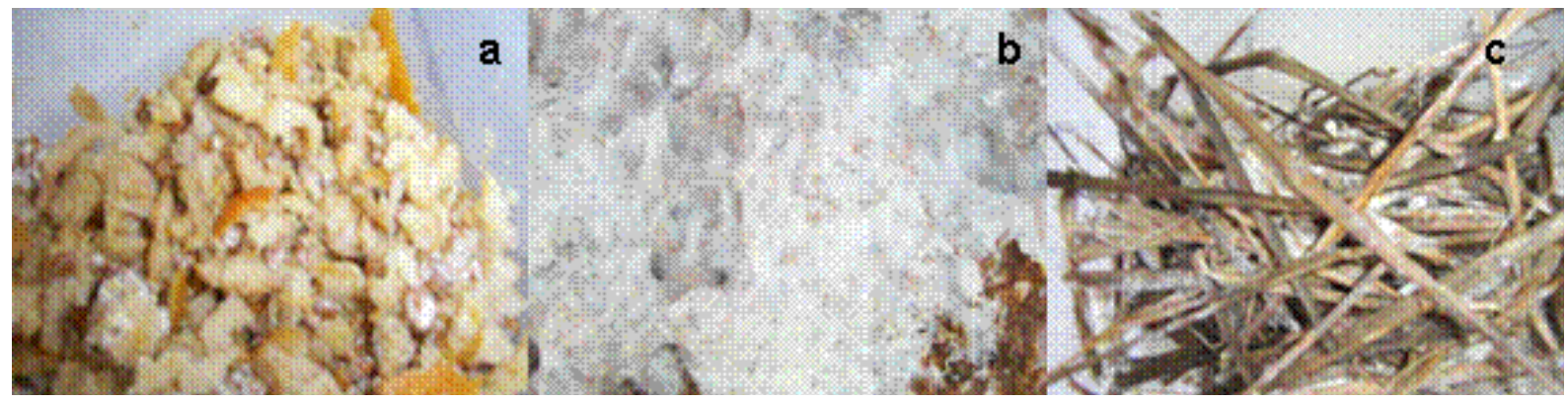

Figure 1. Mycelial colonization by $P$. ostreatus 814 on citrus bagasse and rice straw.

(a) 21 days of fermentation on citrus bagasse.

(b) 44 days of fermentation on citrus bagasse.

(c) 21 days of fermentation on rice straw.

ostreatus 816, Pleurotus cornucopiae y Pleurotus djmour) or from the fermentation product after inoculation of wheat seeds or citrus bagasse. Fresh mycelia or the corresponding fermentation product was grounded under liquid nitrogen in a sterile mortar, to obtain a fine powder. The extraction technique performed followed (Jasalavich et al. 2000), and is based in the classical extraction with cetyltrimethylammonium bromide (CTAB) in the presence of $\beta$-mercaptoethanol, followed by organic extractions and isopropanol precipitation of the DNA. DNA was quantified by spectrophotometrical measurement at 260 and $280 \mathrm{~nm}$ and its integrity was evaluated in $0,8 \%$ agarose gels, using ethidium bromide $(\mathrm{EtBr})$. DNA bands were visualized by the fluorescence of the intercalated EtBr under UV light.

PCR amplification. The ITS region was amplified by PCR from DNA isolated from pure cultures of each of the fungi

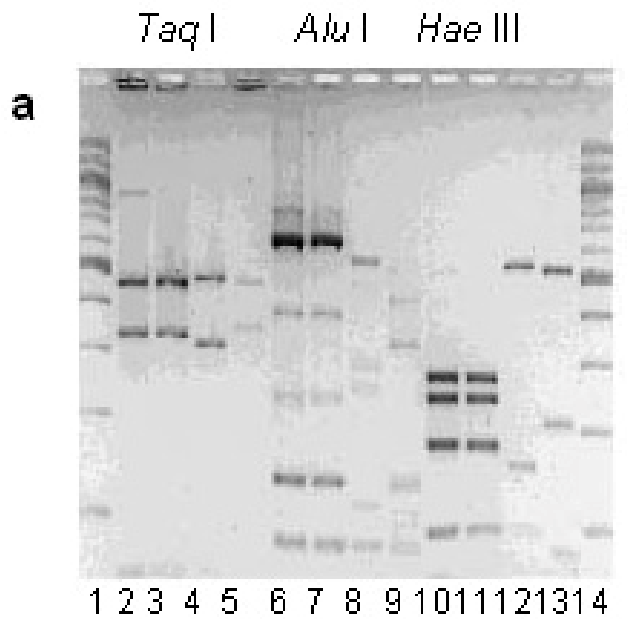

under study and from the corresponding fermentation product. Primers ITS1-F (CTT GGT CAT TTA GAG GAA GTA A) which is specific for the higher fungi, and ITS4 (TCC TCC GCT TAT TGA TAT GC) the universal primer, were used together to amplify the ITS region from higher fungi. The primer pair ITS1-F and ITS4-B (CAG GAG ACT TGT ACA CGG TCC AG), which is specific for basidiomycetes, were used to specifically amplify the ITS region from only basidiomycetes. Amplification were performed in $50 \mu \mathrm{l}$ reactions of PCR buffer (Invitrogen), 5 $\mathrm{mM}$ concentrations of each deoxyribonucleotide triphosphate, 10 pmol concentrations of each appropriate primers, $10 \mathrm{ng}$ of total DNA isolated from a pure culture or from the fermentation product, and $1 \mathrm{U}$ of Taq polymerase (Invitrogen). PCR reactions consisted of denaturation at $94^{\circ} \mathrm{C}$ for 1 min $25 \mathrm{~s}, 35$ cycles of amplification, and a final extension at $72^{\circ} \mathrm{C}$ for $10 \mathrm{~min}$; each cycle of amplification consisted of denaturation at $95^{\circ} \mathrm{C}$ for $35 \mathrm{~s}$, annealing for 55 $\mathrm{s}\left(\right.$ at $55^{\circ} \mathrm{C}$ for reactions with ITS1-F and ITS4 and at $60^{\circ} \mathrm{C}$

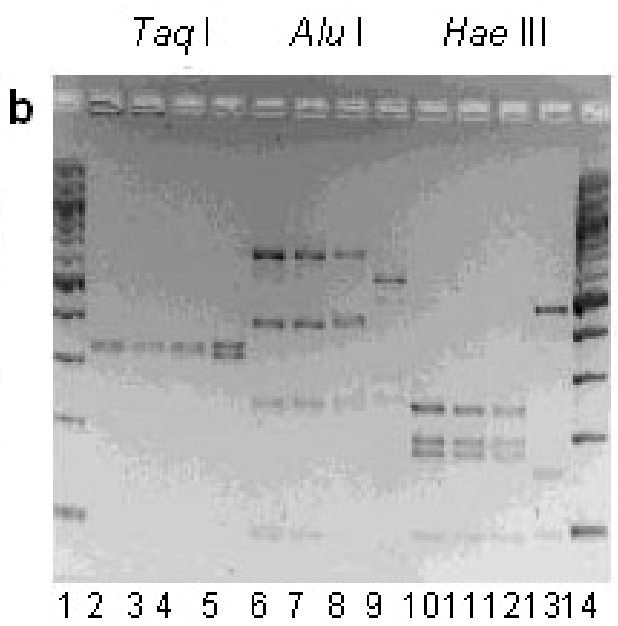

Figure 2. Restriction profiles obtained on restriction with Taq I, Alu I y Hae III.

(a) Amplification with specific primers. 2, 6 and 10: P. ostreatus $814 ; 3,7$ and 11: P. ostreatus 816, 4, 8 and 12: P. cornucopiae; 5, 9 and 13: P. djmour. 1 and 14: Molecular weight marker (Smart ladder, Eurogentec).

(b) Amplification with general primers. 2, 6 and 10: P. ostreatus $814 ; 3,7$ and 11: P. ostreatus 814 (SSF on citric bagasse); 4,8 and 12:

P. ostreatus 816; 5, 9 and 13: P. cornucopiae. 1 and 14: Molecular weight marker (Smart ladder, Eurogentec). 
Table 2. Chemical analysis of the substrates under study at 0,7 and 14 days of fermentation. The values reported are the mean of two measurements.

Substrate: citrus bagasse

Ferm. day Dry weight (w/w) Protein (w/w) ADF (w/w) NDF (w/w)

\begin{tabular}{|c|c|c|c|c|}
\hline 0 & 19.8 & 0.6 & 4.5 & 4.7 \\
\hline 7 & 16.8 & 0.8 & 3.5 & 4.0 \\
\hline 14 & 16.7 & 0.8 & 3.1 & 3.6 \\
\hline
\end{tabular}

Substrate: rice straw

Ferm. day Dry weight (w/w) Protein (w/w) ADF (w/w) NDF (w/w)

\begin{tabular}{|c|c|c|c|c|}
\hline 0 & 27.3 & 0.7 & 17.5 & 18.5 \\
\hline 7 & 22.3 & 0.7 & 12.2 & 14.0 \\
\hline 14 & 18.3 & 0.9 & 10.2 & 11.2 \\
\hline \multicolumn{4}{|c|}{ Substrate: rice straw + citrus bagasse 1:9 w/w } \\
\hline Ferm. day & Dry weight (w/w) & Protein (w/w) ADF (w/w) NDF (w/w) \\
\hline 0 & 20.0 & 0.5 & 6.12 & 6.3 \\
\hline 7 & 14.8 & 0.7 & 4.8 & 5.3 \\
\hline 14 & 14.4 & 0.6 & 4.3 & 4.8 \\
\hline
\end{tabular}

for reactions with ITS1-F and ITS4-B), and extension at $72^{\circ} \mathrm{C}$ for $1 \mathrm{~min}$. PCR products were separated by electrophoresis in $0,8 \%(\mathrm{wt} / \mathrm{vol})$ agarose gels in $1 \mathrm{x}$ TBE ( $89 \mathrm{mM}$ Tris-borate, $89 \mathrm{mM}$ boric acid, 2 mM EDTA) with $\mathrm{EtBr}$ at $100 \mathrm{ng} / \mathrm{ml}$ in the geland running buffer; DNA bands were visualized by the fluorescence of the intercalated $\mathrm{EtBr}$ under UV light and photographed. Molecular weight markers were run together with the samples.

Restriction digestion of PCR products. PCR reaction products were digested directly without further purification with restriction endonucleases to obtain RFLPs; each sample was digested with AluI (Biolabs), HaeIII (Biolabs) and TaqI (Biolabs) in single-enzyme digests. $10 \mu \mathrm{l}$ of amplified PCR reaction was mixed with the appropriate restriction reaction buffer and $10 \mathrm{U}$ of the appropriate enzyme and then incubated for $6 \mathrm{hrs}$ at $37^{\circ} \mathrm{C}$ for the $A l u \mathrm{I}$ or HaeIII digests or at $65^{\circ} \mathrm{C}$ for the TaqI digests. Restriction fragments were separated by electrophoresis in 3\% (wt/vol) agarose in $1 \mathrm{x}$ TAE $(40 \mathrm{mM}$ Tris acetate, $1 \mathrm{mM}$ sodium EDTA) with $\mathrm{EtBr}$ at $100 \mathrm{ng} / \mathrm{ml}$ in the gel and running buffer. DNA bands were visualized by fluorescence under UV light and photographed.

\section{RESULTS AND DISCUSSION}

\section{Determination of the capacity to grow on the wastes}

At 7 days of fermentation fungal growth is already appreciated on all the substrates under study, with all the strains assayed. A greater colonization is achieved at day 21 with P. ostreatus 814 (Figure 1).

\section{Determination of the microbiological quality}

Although an increase in the total aerobic count is seen for citrus bagasse with respect to day 0 , no appreciable increase in total coliforms or E. coli is appreciated (Table 1).

\section{Analysis of the chemical composition}

After fermentation, a decrease in the dry weight, increase in the levels of proteins and a decrease in the values of neutral detergent fiber (hemicellulose, cellulose and lignin) and acid detergent fiber (lignin and cellulose) were detected (Table 2). These last determinations could be indicative of the degradation of the cell wall components of the substrates produced by the extracellular enzymes of $P$. 
ostreatus. Previous authors concluded that lignification of structural polysaccharides not only inhibited ruminal microbial digestion of polysaccharides by forming 3-D matrix, but also that the presence of highly lignified tissues formed a physical barrier preventing the accessibility of the otherwise highly digestible tissues to the action of hydrolytic enzyme of the rumen microorganisms (Karunanandaa et al. 1995), and have shown that increased digestibility was associated with the degradation of structural carbohydrates (Mukherjee and Nandi, 2004).

No nitrogen source was added, as previous work showed that the in vitro digestibility of the fermented substrate was decreased as compared with fermentation substrate not amended with nitrogen.

\section{Molecular characterization of the strains under study}

When using primers ITS1F and ITS4B, specific for basidiomycetes, an interspecies polymorphism is observed in the band profile obtained, whilst there is no difference observed within a same species (Figure 2a). When making the amplification with primers ITS1F and ITS4, general for higher fungi, the same restriction profile for fungi of the same species ( $P$. ostreatus 814 and 816$)$ is obtained. This same profile is obtained when DNA is extracted from the substrates under study colonized by $P$. ostreatus 814 . It is important to emphasize that when using these general primers no additional bands, that could correspond to other fungi, were obtained (Figure $2 b$ ).

These results show not only that strain in use in the mushroom producing industry can be identified to species level using molecular techniques, but also that it is plausible to carry out a molecular characterization of the fermentation products (Villas-Boas et al. 2002).

\section{CONCLUDING REMARKS}

From the results obtained, we can conclude that $P$. ostreatus 814 is an appropriate strain to use as inocula of the agroindustrial wastes under study. Higher protein levels, better conservation of the substrate and an increase in in vitro digestibility is observed. A scale up process, using rice straw bales in the open, is under way.

\section{REFERENCES}

ADAMOVIC, M.; GRUBIC, G.; MILENKOVIC, I.; JOVANOVIC, R.; PROTIC, R.; STRETENOVIC, L. and STOICEVIC, L. The biodegradation of wheat straw by Pleurotus ostreatus mushrooms and its use in cattle feeding. Animal Feed Science and Technology, April 1998, vol. 71, no. 3-4, p. 357-362.

AOAC. Association of Official Analytical Chemists. Official Methods of Analysis. $15^{\text {th }}$ ed. Arlington, VA. 1990.
AOAC. Association of Official Analytical Chemists. Official Methods of Analysis. 16 ${ }^{\text {th }}$ ed. Arlington, VA. 1996.

BREENE, W.M. Nutritional and medicinal value of specialty mushrooms. Journal of Food Protection, October 1990, vol. 53, no. 10, p. 883-894.

CALZADA, J.F.; FRANCO, L.F.; DE ARRIOLA, M.C.; ROLZ, C. and ORTIZ, M.A. Acceptability, body weight changes and digestibility of spent wheat straw after harvesting of Pleurotus sajor-caju. Biological Wastes, 1987, vol. 22, no. 4, p. 303-309.

COMMANDAY, F. and MACY, J.M. Effect of substrate nitrogen on lignin degradation by Pleurotus ostreatus. Archives of Microbiology, June 1985, vol. 142, no. 1, p. 6165.

JASALAVICH, C.; OSTROFSKY, A. and JELLISON, J. Detection and identification of decay fungi in spruce wood by restriction fragment length polymorphism analysis of amplified genes encoding rRNA. Applied and Environmental Microbiology, November 2000, vol. 66, no. 11, p. 4725-4734.

KAKKAR, V.K. and DAÑAD, S. Comparative evaluation of wheat and paddy straws for mushroom production and feeding residual straws to ruminants. Bioresource Technology, November 1998, vol. 66, no. 2, p. 175-177.

KARUNANANDAA, K.; VARGA, G.A.; AKIN, D.E.; RIGSBY, L.L. and ROYSE, D.J. Botanical fractions of rice straw colonized by white-rot fungi: changes in chemical composition and structure. Animal Feed Science and Technology, October 1995, vol. 55, no. 3-4, p. 179-199.

MANN, H.B. and WHITNEY, D.R. On a test of whether one or two random variables is stochastically larger than the other. The Annals of Mathematical Statistics, 1947, vol. 18 , p. 50-60.

MUKHERJEE, R. and NANDI, B. Improvement of in vitro digestibility through biological treatment of water hyacinth biomass by two Pleurotus species. International Biodeterioration and Biodegradation, January 2004, vol. 53, no. 1, p. 7-12.

PLATT, W.M.; HADER, Y. and CHET, I. Fungal activities involved in lignocellulose degradation by Pleurotus. Applied Microbiology and Biotechnology, August 1984, vol. 20, no. 2, p. 150-154.

RAJARATHNAM, S. and BANO, Z. Pleurotus mushrooms III. Biotransformation of natural lignocellulosic wastes: commercial applications and implications. Critical Reviews in Food Sciences and Nutrition, 1989, vol. 28, no. 1, p. 31113.

SALMONES, D.; MATA, G. and WALISZEWSKI, K.N. Comparative culturing of Pleurotus spp. on coffee pulp and 
wheat straw: biomass production and substrate biodegradation. Bioresourse Technology, March 2005, vol. 96 , no. 5, p. 537-544.

SERMANNI, G.G.; D'ANNIBALE, A.; DI LENA, G.; VITALE, N.S.; DI MATTIA, E. and MINELLI, V. The production of exo-enzymes by Lentinus edodes and Pleurotus ostreatus and their use for upgrading corn straw. Bioresource Technology, 1994, vol. 48, no. 2, p. 173-178.

VILLAS-BOAS, S.G.; ESPOSITO, E. and MITCHELL, D.A. Microbial conversion of lignocellulosic residues for production of animal feeds. Animal Feed Science and Technology, July 2002, vol. 98, no. 1-2, p. 1-12.

YILDIZ, S.; YILDIZ, U.C.; GEZER, E.D. and TEMIZ, A. Some lignocellulosic wastes used as raw material in cultivation of the Pleurotus ostreatus culture mushroom. Process Biochemistry, November 2002, vol. 38, no. 3, p. 301-306.

ZHANG, R.; LI, X. and FADEL, J.G. Oyster mushroom cultivation with rice and wheat straw. Bioresource Technology, May 2002, vol. 82, no. 3, p. 277-284. 